\title{
Synthesis and Characterization of Novel Five-Membered Heterocycles and Their Activity against Candida Yeasts
}

\author{
Hiba Maher Tawfeeq, ${ }^{1}$ Rasim Farraj Muslim, ${ }^{2}$ Obaid Hasan $\mathrm{Abid}^{3}$ \\ and Mustafa Nadhim Owaid ${ }^{2,4}$ \\ ${ }^{1}$ Department of Chemistry, College of Education for Pure Sciences, University Of Anbar, Anbar 31001, Iraq \\ ${ }^{2}$ Department of Ecology, College of Applied Sciences, University Of Anbar, Anbar 31007, Iraq \\ ${ }^{3}$ Department of Scientific Affairs and Graduate Studies, University of Fallujah, Anbar, Iraq \\ ${ }^{4}$ Department of Heet Education, General Directorate of Education in Anbar, Ministry of Education, Anbar 31007, Iraq \\ *Corresponding author: E-mail: dr.rasim92hmts@gmail.com
}

Received: 09-14-2018

\begin{abstract}
Some new tetrazole derivatives were prepared by the reaction between the prepared azomethine compounds $\mathbf{I}_{\mathbf{6}}-\mathbf{I}_{\mathbf{1 0}}$ with sodium azide in anhydrous tetrahydrofuran (THF) with a few drops of distilled water and under reflux conditions. Azomethine compounds were prepared by thermal condensation reactions of aromatic aldehydes with primary aromatic amines. The prepared compounds (tetrazole derivatives) were screened for their antibacterial activity (by disc diffusion method). Compound $\mathbf{I}_{\mathbf{6}}$ is the most active derivative that has recorded a significantly $(p<0.01)$ stronger influence to inhibit the growth of Candida zeylanoides with an average zone of inhibition of $26.0 \mathrm{~mm}$. Derivatives $\mathbf{I}_{\mathbf{7}}$ and $\mathbf{I}_{\mathbf{9}}$ showed the lowest zone of inhibition of $8.0 \mathrm{~mm}$ against Candida zeylanoides. This study may be helpful in designing more potential anticandidal agents for therapeutic use in the future.
\end{abstract}

Keywords: Candida sp.; pharmaceutical; azomethine; sodium azide; biological activity.

\section{Introduction}

Azomethine compounds discovered by Hugo Schiff in 1864 , can be prepared by different methods, one of the more important being the condensation reaction between primary amine with aldehyde. ${ }^{1}$ Azomethine compounds contain the $\mathrm{N}=\mathrm{C}$ group. ${ }^{2}$ Some of the azomethine compounds are used as antibacterial agents. ${ }^{3,4}$ The structure of azomethine compounds usually includs a phenyl or aryl group with the double bond between the carbon atom and the nitrogen atom. ${ }^{5,6}$ (Scheme 1)

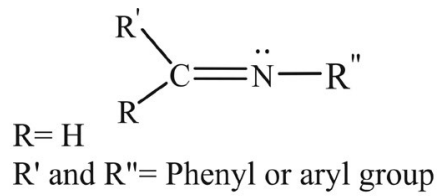

Scheme 1. Structure of azomethine compounds
The reaction of triazole diamine compound with 4-bromobenzaldehyde in the presence of glacial acetic acid gave the next product. ${ }^{7}$ (Scheme 2 )

Tetrazole derivatives are heterocyclic compounds containing four nitrogen atoms and one carbon atom within one ring. ${ }^{8}$ Tetrazoles as a group of heterocyclic compounds appear in IR spectra as broad signals; having peculiar biological activities., ${ }^{9,10}$ Tetrazole derivatives have a special structure and can display anti-bacterial properties, such as antiviral and anti-allergic. ${ }^{11-13}$ There are several methods to prepare tetrazole derivatives, and each method depends on the constituents of the reaction. ${ }^{14}$ Recently, there were many various types of compounds (including such containing a metal centre coordinated with suitable ligands) tested against Candida albicans, with a varying degree of success. ${ }^{15-17}$ An example of one of tetrazole derivatives is the product from the reaction between azomethine compound (biphenyl bis 


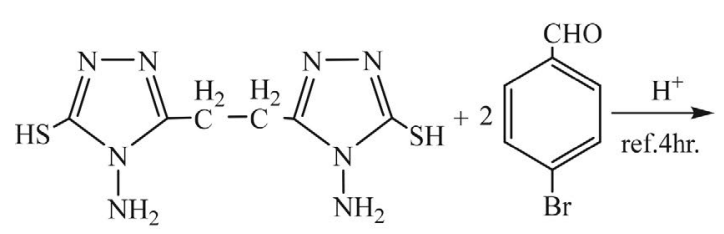

5,5'-(ethane-1,2-diyl)bis(4-amino 4-bromobenzaldehyde $-4 H-1,2,4$-triazole-3-thiol)<smiles>Sc1nnc(CCc2nnc(S)n2N=Cc2ccccc2)n1N=Cc1ccccc1</smiles>

(E)-5,5'-(ethane-1,2-diyl)bis(4-((E)-benzyl ideneamino)-4H-1,2,4-triazole-3-thiol)

Scheme 2. Using glacial acetic acid to prepare the azomethine compound

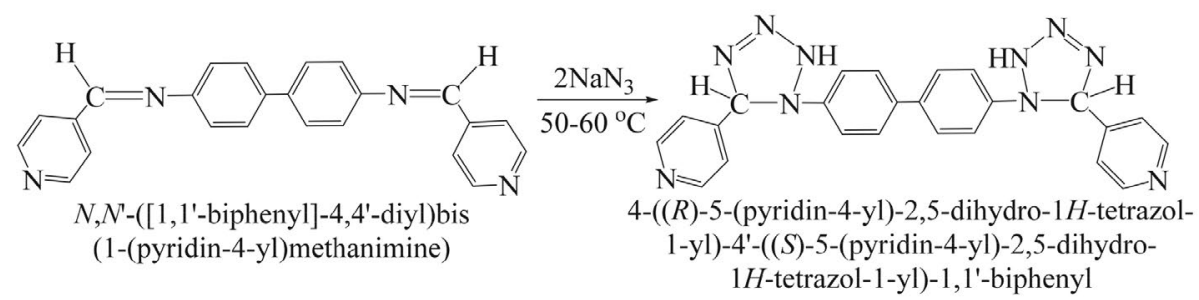

Scheme 3. Use of sodium azide to prepare tetrazole derivatives

(1-(pyridin-4-yl) methanimine)) with sodium azide. ${ }^{18}$ (Scheme 3)

Many of tetrazole derivatives can be prepared by the reaction between a different aldehyde and different amines..$^{10}$ (Scheme 4)

In this study, tetrazole derivatives derived from the reaction of the prepared azomethine compounds with sodium azide were evaluated for their biological activity against four types of Candida yeasts. The products were identified by their melting points, FT-IR and ${ }^{1} \mathrm{H}$ NMR spectra.

\section{Experimental}

\section{1. Apparatuses}

The measurement of melting point was conducted by the electrothermal melting point apparatus. IR spectra were recorded at room temperature in the range of 400-4000 $\mathrm{cm}^{-1}$ by a Fourier transform infra-red Spectrophotometer Model Tensor 27 Bruker Co., Germany. The ${ }^{1} \mathrm{H}$ NMR spectra were recorded on Bruker Ac-300 MHz spectrometer.

\section{2. Preparation of Azomethine Compounds $\mathrm{I}_{1}-\mathrm{I}_{5}$}

Azomethine compounds were prepared according to the literature procedure, ${ }^{19,20}$ as shown in Table 1. An equimolar mixture 0.02 mole of aldehydes and 0.02 mole of amines and trace of acidic catalyst in $25 \mathrm{~mL}$ absolute ethanol were reacted at reflux temperature for 4 hours, whereby a crystalline solid separated out. The products were filtered off and recrystallized from absolute ethanol.

\section{3. Preparation of Tetrazole Derivatives $I_{6}-I_{10}$}

A mixture of azomethine compounds $(0.01 \mathrm{~mol})$ and sodium azide $(0.01 \mathrm{~mol})$ was dissolved in $20 \mathrm{~mL}$ of THF and $2 \mathrm{~mL}$ distilled water and refluxed for 4 hour and left to stand for 24 hour at room temperature, then the solid product separated out. ${ }^{21}$ The products were filtered off and recrystallized from absolute ethanol as shwon in Table 2.

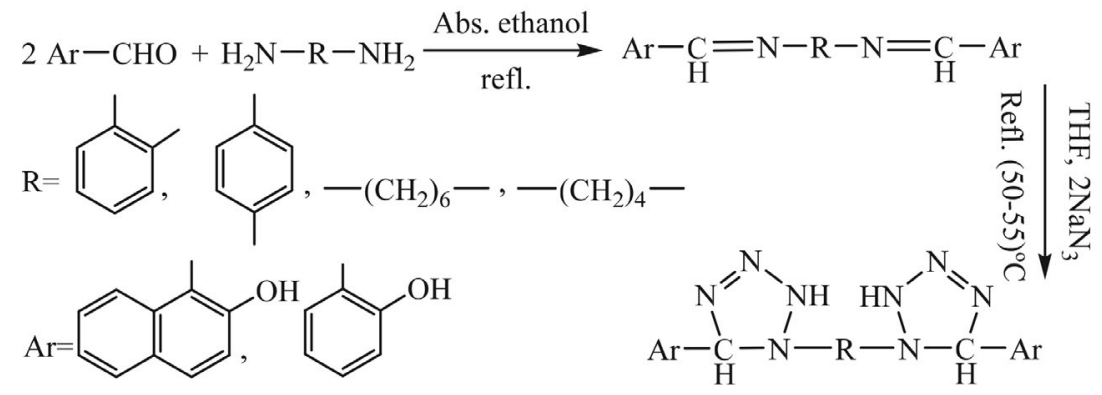

Scheme 4. Prepared tetrazole derivatives with double rings 
Table 1. Names, structural formulae, symbol, yields, colors and melting points of azomethine compounds $\mathrm{I}_{1}-\mathrm{I}_{5}$

\begin{tabular}{|c|c|c|c|c|c|}
\hline Nomenclature & Structural formula & Compound & Yield \% & Color & m.p. ${ }^{\circ} \mathrm{C}$ \\
\hline $\begin{array}{l}\text { (E)-4,6-dimethyl- } N \text {-(4-nitro } \\
\text { benzylidene) pyrimidin-2-amine }\end{array}$ & & $\mathrm{I}_{1}$ & $78 \%$ & $\begin{array}{l}\text { Bright } \\
\text { pale } \\
\text { yellow }\end{array}$ & $79-81$ \\
\hline $\begin{array}{l}(E)-5 \text {-((2-(2,4-dinitro phenyl) } \\
\text { hydrazono)methyl)-2- } \\
\text { methoxyphenol }\end{array}$ & & $\mathbf{I}_{2}$ & $80 \%$ & Dark red & $250-252$ \\
\hline $\begin{array}{l}\text { (E)-1-(4-chlorobenzylidene) } \\
\text {-2-(2,4-dinitro phenyl) } \\
\text { hydrazine }\end{array}$ & & $\mathbf{I}_{3}$ & $82 \%$ & Orange & $236-238$ \\
\hline $\begin{array}{l}(E) \text {-1-(4-bromobenzyl idene) } \\
\text {-2-(2,4-dinitro phenyl) } \\
\text { hydrazine }\end{array}$ & & $\mathbf{I}_{4}$ & $84 \%$ & Orange & $232-234$ \\
\hline $\begin{array}{l}(E)-4-((2-(2,4-d i n i t r o ~ p h e n y l) \\
\text { hydrazono) methyl)phenol }\end{array}$ & & $\mathbf{I}_{5}$ & $80 \%$ & $\begin{array}{c}\text { Bright } \\
\text { Dark red }\end{array}$ & $240-242$ \\
\hline
\end{tabular}

Table 2. Names, structural formulae, symbol, yields, colors and melting points of tetrazole derivatives $\mathrm{I}_{6}-\mathrm{I}_{10}$

\begin{tabular}{|c|c|c|c|c|c|}
\hline Nomenclature & Structural formula & Compound & Yield \% & Color & m.p. ${ }^{\circ} \mathrm{C}$ \\
\hline $\begin{array}{l}\text { 4,6-dimethyl-2-(5-( } p \text {-nitro } \\
\text { phenyl })-4,5 \text {-dihydro- } 1 H \text { - } \\
\text { tetrazol-yl)pyrimidine }\end{array}$ & & $\mathbf{I}_{6}$ & $76 \%$ & Bright tan & $96-98$ \\
\hline $\begin{array}{l}\text { 5-((2,4-dinitrophenyl) } \\
\text { amino)-4,5-dihydro- } 1 H \text { - } \\
\text { tetrazol-yl-2-methoxy phenol }\end{array}$ & & $\mathbf{I}_{7}$ & $83 \%$ & Red & $276-279$ \\
\hline $\begin{array}{l}5 \text {-( } p \text {-chlorophenyl })-\mathrm{N}-(2,4 \text { - } \\
\text { dinitrophenyl })-4,5 \text {-dihydro - } \\
1 H \text {-tetrazol-1-amine }\end{array}$ & & $\mathbf{I}_{8}$ & $78 \%$ & Orange & $256-258$ \\
\hline $\begin{array}{l}\text { 5-( } p \text {-bromophenyl })-\mathrm{N}-(2,4- \\
\text { dinitrophenyl })-4,5 \text {-dihydro - } \\
1 H \text {-tetrazol-1-amine }\end{array}$ & & $\mathbf{I}_{9}$ & $78 \%$ & Orange & $260-262$ \\
\hline $\begin{array}{l}\text { 4-(1-((2,4-dinitrophenyl) } \\
\text { amino)-4,5-dihydro- } 1 H \text { - } \\
\text { tetrazol-yl }) \text { phenol }\end{array}$ & $\mathrm{NO}_{2}$ & $I_{10}$ & $92 \%$ & Orange & $272-274$ \\
\hline
\end{tabular}

\section{4. Activity against Candida Yeasts}

This test was carried out in vitro to investigate the inhibitory effects of the prepared tetrazole derivatives using well diffusion method on Muller-Hinton agar. This experiment was done as mentioned by Owaid et al. with some modifications. ${ }^{22}$ Four milligrams of the prepared tetrazole derivatives were applied separately in $6 \mathrm{~mm}$-well. After 18 hour at $37^{\circ} \mathrm{C}$, the zone of inhibition was measured using the ruler in millimeters.

\section{Results and Discussion}

Tables 1 and 2 show structural formulae, names, yields, melting points and color of all prepared compounds $\mathbf{I}_{1}-\mathbf{I}_{\mathbf{1 0}}$. The best yield achieved for the prepared azomethine compounds was for compounds $I_{3} 82 \%$ and $I_{4} 84 \%$, while the lowest yield was for compound $I_{1} 78 \%$ and the best yield of the prepared tetrazole derivatives was for $\mathbf{I}_{\mathbf{1 0}}$ $92 \%$, while the lowest yield was for $\mathbf{I}_{6} 76 \%$. The highest melting point for azomethine compounds was for com- 
pound $\mathbf{I}_{2}$, the lowest melting point was for compound $\mathbf{I}_{1}$, while the highest melting point of the prepared tetrazole derivatives was for compound $\mathbf{I}_{7}$, the lowest melting point was for compound $\mathbf{I}_{\mathbf{6}}$. The different colors and melting points of the products compared with the raw material are initial evidence of interaction.

\section{1. Azomethine Compounds $I_{1}-I_{5}$}

Azomethine compounds were prepared from commercially available aldehydes with primary amines and identified by their melting points and FT-IR spectra. Table 3 shows the appearance of the stretching absorption bands of the characteristic groups of the resulting group $(\mathrm{C}=\mathrm{N})$ at $1609-1681 \mathrm{~cm}^{-1}$ beside the characteristic bands of the residual groups in the structure, being indicative of the formation of the products. ${ }^{23,24} 3,4,9 \mathrm{a}$ - Tetrahydrobenzo [e] $[1,3]$ oxazepin- $5(5 \mathrm{aH}$
The reaction involves a nucleophile attack of the electron pair of the amino group $\left(\mathrm{NH}_{2}\right)$ of aromatic amine on the carbonyl group $(\mathrm{C}=\mathrm{O})$ of aromatic aldehydes to form an $\mathrm{N}$-substituted hemiaminal; in a suitable medium it can eliminate a water molecule to give the stable compound (azomethine). ${ }^{20}$

\section{2. Tetrazole Derivatives $I_{6}-I_{10}$}

In this work, the preparation of tetrazole compounds was achieved by the reaction between prepared azomethine compounds $\left(\mathbf{I}_{1}-\mathbf{I}_{5}\right)$ with sodium azide. The resulting products were identified using the melting points, FT-IR and ${ }^{1} \mathrm{H}$ NMR spectra. Table 4 shows characteristic stretching absorption bands at $1219-1286 \mathrm{~cm}^{-1}, 1007-1083 \mathrm{~cm}^{-1}$ and $1487-1509 \mathrm{~cm}^{-1}$ indicative of $\mathrm{C}-\mathrm{N}, \mathrm{N}-\mathrm{N}$ and $\mathrm{N}=\mathrm{N}$ bonds of tetrazol rings beside the characteristic stretching absorption bands of the residual groups in their structure. ${ }^{27}$

Table 3. FT-IR of azomethine compounds $\mathbf{I}_{\mathbf{1}}-\mathbf{I}_{\mathbf{5}}$

\begin{tabular}{|c|c|c|c|c|c|c|c|}
\hline \multirow{3}{*}{ Compound } & \multicolumn{6}{|c|}{ FT-IR, $v\left(\mathrm{~cm}^{-1}\right)$} & \multirow{3}{*}{ Others } \\
\hline & $\mathrm{C}=\mathrm{N}$ & $\mathrm{C}=\mathrm{C}$ & \multicolumn{2}{|c|}{$\mathrm{C}-\mathrm{H}$} & \multicolumn{2}{|c|}{ C-H Aliphatic } & \\
\hline & & Aromatic & Aromatic & Alkene & Asymmetric & Symmetric & \\
\hline $\mathbf{I}_{\mathbf{1}}$ & 1681 & 1601 & 3042 & 3105 & 2969 & 2849 & $\begin{array}{c}\mathrm{NO}_{2} 1529,1340, \\
\mathrm{C}=\mathrm{N} \text { pyrimidine } 1634\end{array}$ \\
\hline $\mathbf{I}_{2}$ & 1609 & 1580 & 3042 & 3113 & 2972 & 2945 & $\begin{array}{c}\mathrm{NO}_{2} 1500,1328 \\
\mathrm{O}-\mathrm{H} 3491, \mathrm{NH} 3278\end{array}$ \\
\hline $\mathbf{I}_{3}$ & 1609 & 1581 & 3041 & 3089 & - & - & $\begin{array}{c}\mathrm{NO}_{2} 1508,1317 \\
\mathrm{~N}-\mathrm{H} 3283, \mathrm{C}-\mathrm{Cl} 823\end{array}$ \\
\hline $\mathrm{I}_{4}$ & 1611 & 1581 & 3042 & 3087 & - & - & $\begin{array}{c}\mathrm{NO}_{2} 1505,1324 \\
\mathrm{~N}-\mathrm{H} 3263\end{array}$ \\
\hline $\mathbf{I}_{5}$ & 1615 & 1592 & 3042 & 3112 & - & - & $\begin{array}{c}\mathrm{NO}_{2} 1508,1305 \\
\mathrm{O}-\mathrm{H} 3422, \mathrm{~N}-\mathrm{H} 3257\end{array}$ \\
\hline
\end{tabular}

The general equation (Scheme 5) represents the main reaction through which the prepared azomethine compounds were obtained. The mechanism of azomethine compounds formation was thoroughly studied and established by many authors in the literature. ${ }^{25,26}$

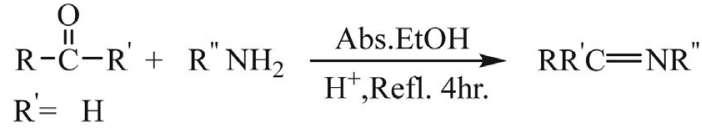

$$
\begin{aligned}
& \mathrm{R}^{\prime \prime}=\underbrace{\mathrm{N}_{\mathrm{N}}}_{\mathrm{NO}_{2}} \\
& \text { Cl }
\end{aligned}
$$

Scheme 5. The main reaction of azomethine compounds
The ${ }^{1} \mathrm{H}$ NMR spectrum of compound $\mathbf{I}_{7}$ (Fig. 1, in solvent DMSO- $d_{6}$ ) showed the following signals: singlet at $\delta 1.76$ indicating the presence of $3 \mathrm{H}$ as o methoxy group $\left(\mathrm{OCH}_{3}\right)$, singlet at $\delta 3.83$ indicating the presence of $1 \mathrm{H}$ as an $\mathrm{NH}$ group ( $\mathrm{NH}$ outside of the tetrazole ring), singlet at $\delta 8.55$ indicating the presence of $1 \mathrm{H}$ as another $\mathrm{NH}$ group ( $\mathrm{NH}$ inside of the tetrazole ring), singlet at $\delta 9.33$ indicating the presence of $1 \mathrm{H}$ as one $\mathrm{CH}$ group $(\mathrm{N}-\mathrm{CH})$, singlet at $\delta 11.56$ indicating the presence of $1 \mathrm{H}$ as one hydroxy group $(\mathrm{OH})$, multiplet at $\delta 8.96-6.99$ indicating the presence of $6 \mathrm{H}$ of aromatic protons. ${ }^{1} \mathrm{H}$ NMR spectrum of compound $\mathbf{I}_{\mathbf{8}}$ (Fig. 2) shows the following signals: singlet at $\delta 3.33$ indicating the presence of $1 \mathrm{H}$ as an $\mathrm{NH}$ group $(\mathrm{NH}$ outside of the tetrazole ring), singlet at $\delta 8.71$ indicating the presence of $1 \mathrm{H}$ as another $\mathrm{NH}$ group ( $\mathrm{NH}$ inside of the tetrazole ring), singlet at $\delta 11.71$ indicating the presence of $1 \mathrm{H}$ as one $\mathrm{CH}$ group $(\mathrm{N}-\mathrm{CH})$, multiplet and doublet of doublet at $\delta 8.41-7.56$ indicating the presence of $7 \mathrm{H}$ of aromatic protons. ${ }^{27}$ Other chemical shifts for compounds $\mathbf{I}_{\mathbf{6}}$, $\mathbf{I}_{9}$ and $\mathbf{I}_{10}$ are given in Table 5 . 
Table 4. FT-IR of tetrazole derivatives $\mathbf{I}_{\mathbf{6}}-\mathbf{I}_{\mathbf{1 0}}$

\begin{tabular}{|c|c|c|c|c|c|c|c|c|c|}
\hline \multirow{3}{*}{ Compound } & \multirow{3}{*}{$\mathbf{N}-\mathbf{H}$} & \multirow{3}{*}{$\mathbf{N}-\mathbf{N}$} & \multirow{3}{*}{$\mathbf{N}=\mathbf{N}$} & \multirow{3}{*}{$\mathrm{C}-\mathrm{N}$} & \multicolumn{2}{|c|}{ FT-IR $v\left(\mathrm{~cm}^{-1}\right)$} & \multirow{2}{*}{\multicolumn{2}{|c|}{ C-H Aliphatic }} & \multirow{3}{*}{ Others } \\
\hline & & & & & $\mathrm{C}=\mathrm{C}$ & C-H & & & \\
\hline & & & & & Aromatic & Aromatic & Asymmetric & Symmetric & \\
\hline$I_{6}$ & 3383 & 1007 & 1500 & 1286 & 1606 & 3044 & 2976 & 2849 & $\mathrm{NO}_{2} 1541,1345$ \\
\hline $\mathrm{I}_{7}$ & 3280 & 1020 & 1509 & 1273 & 1614 & 3113 & 2972 & 2880 & $\begin{array}{c}\mathrm{O}-\mathrm{H} \text { b } 3497 \\
\mathrm{NO}_{2} 1540,1339 \\
\mathrm{NO}_{2} 1514,1339\end{array}$ \\
\hline $\mathbf{I}_{8}$ & 3266 & 1083 & 1489 & 1219 & 1615 & 3088 & - & - & $\begin{array}{c}\mathrm{C}-\mathrm{Cl} 833 \\
\mathrm{C}-\mathrm{H} 2951 \\
\mathrm{NO}_{2} 1512,1330\end{array}$ \\
\hline$I_{9}$ & 3299 & 1083 & 1487 & 1269 & 1585 & 3067 & - & - & $\begin{array}{c}\text { C-H } 2950 \\
\text { O-H b } 3423\end{array}$ \\
\hline$I_{10}$ & 3258 & 1074 & 1488 & 1276 & 1612 & 3113 & - & - & $\begin{array}{c}\mathrm{NO}_{2} 1509,1305 \\
\text { C-H } 2977\end{array}$ \\
\hline
\end{tabular}

Table 5. The ${ }^{1} \mathrm{H}$ NMR spectral data of tetrazole derivatives $\mathbf{I}_{\mathbf{6}}-\mathbf{I}_{\mathbf{1 0}}$ (in DMSO- $d_{6}$ ).

\begin{tabular}{|c|c|}
\hline Compound & Chemical Shifts $\delta$ (ppm) \\
\hline$I_{6}$ & $\begin{array}{l}\text { Singlet at } 1.28\left(6 \mathrm{H}, 2 \underline{\mathrm{CH}_{3}}\right) \text {, singlet at } 8.68(\mathrm{H},-\underline{\mathrm{NH}}) \text {, singlet at } 10.19(1 \mathrm{H}, \mathrm{N}-\underline{\mathrm{CH}}) \text {, singlet at } 9.77(1 \mathrm{H},-\underline{\mathrm{OH}}) \text {, singlet and doublet of } \\
\text { doublet at } 8.43-8.08(5 \mathrm{H} \text {, aromatic protons). }\end{array}$ \\
\hline $\mathbf{I}_{7}$ & $\begin{array}{l}\text { Singlet at } 1.76\left(3 \mathrm{H}, \mathrm{O}-\mathrm{CH}_{3}\right) \text {, singlet at } 3.83(1 \mathrm{H}, \underline{\mathrm{NH} \text { out }}) \text {, singlet at } 8.55(1 \mathrm{H}, \underline{\mathrm{NH}} \text { in }) \text {, singlet at } 9.33(1 \mathrm{H}, \mathrm{N}-\underline{\mathrm{CH}}) \text {, singlet at } 11.56 \\
(1 \mathrm{H},-\mathrm{OH}) \text {, multiplet at } 8.96-6.99(6 \mathrm{H} \text {, aromatic protons }) \text {. }\end{array}$ \\
\hline $\mathbf{I}_{8}$ & $\begin{array}{l}\text { Singlet at } 3.33(1 \mathrm{H}, \mathrm{NH} \text { outside of the tetrazole ring), singlet at } 8.71(1 \mathrm{H}, \mathrm{NH} \text { inside of the tetrazole ring), singlet at } 11.71 \\
(1 \mathrm{H}, \mathrm{N}-\mathrm{CH}) \text {, multiplet and doublet of doublet at } 8.41-7.56(7 \mathrm{H} \text {, aromatic protons). }\end{array}$ \\
\hline$I_{9}$ & $\begin{array}{l}\text { Singlet at } 3.26(1 \mathrm{H}, \underline{\mathrm{NH}} \text { outside of the tetrazole ring), singlet at } 8.69(1 \mathrm{H}, \underline{\mathrm{NH}} \text { inside of the tetrazole ring), singlet at } 11.71 \\
(1 \mathrm{H}, \mathrm{N}-\mathrm{CH}) \text {, multiplet at } 8.41-7.79(7 \mathrm{H} \text {, aromatic protons). }\end{array}$ \\
\hline$I_{10}$ & $\begin{array}{l}\text { Singlet at } 3.40(1 \mathrm{H}, \underline{\mathrm{NH} \text { out }}), \text { singlet at } 8.88(1 \mathrm{H}, \underline{\mathrm{NH} \text { in }}) \text {, singlet at } 10.07(\mathrm{H}, \mathrm{N}-\underline{\mathrm{CH}}) \text {, singlet at } 11.57(1 \mathrm{H},-\underline{\mathrm{OH}}) \text {, multiplet } \\
\text { and doublet of doublet at } 8.59-6.85 \mathrm{fr}(7 \mathrm{H} \text {, aromatic protons). }\end{array}$ \\
\hline
\end{tabular}

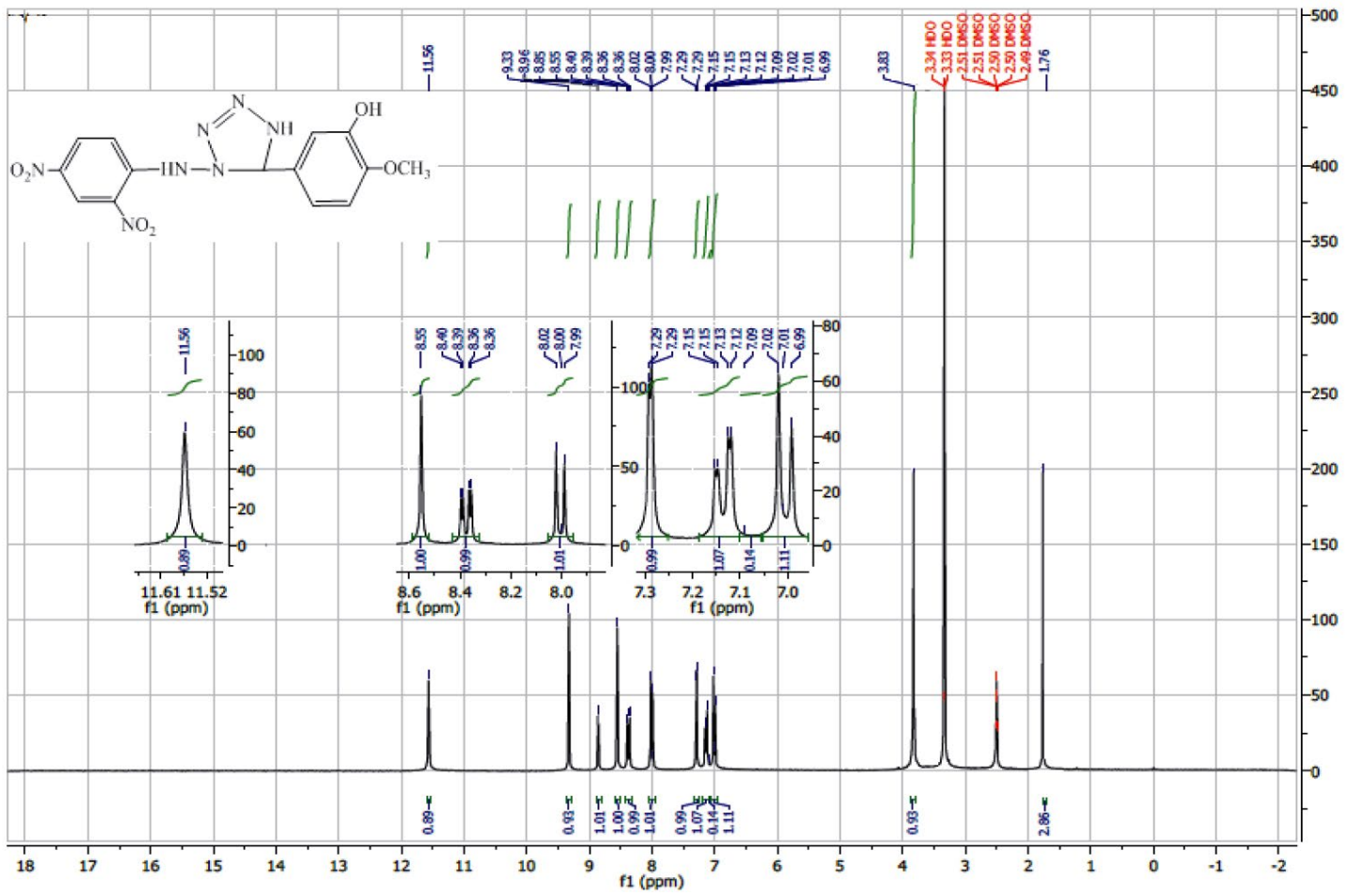

Figure 1. ${ }^{1} \mathrm{H}$ NMR Spectrum of $\mathbf{I}_{7}$ 


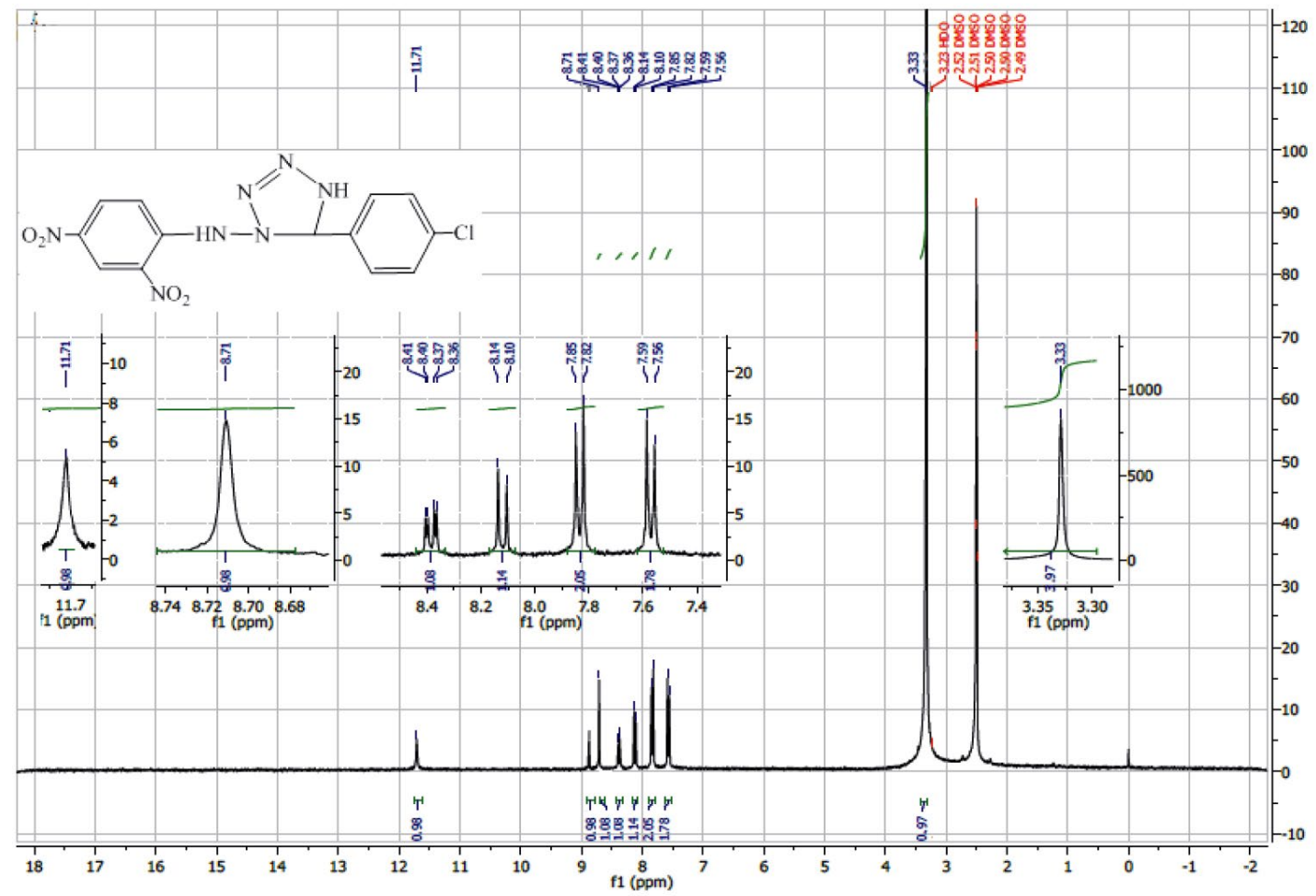

Figure 2. ${ }^{1} \mathrm{H}$ NMR Spectrum of $\mathbf{I}_{\mathbf{8}}$

The reaction of the azomethine compounds with sodium azide is given in the equation in Scheme 6.

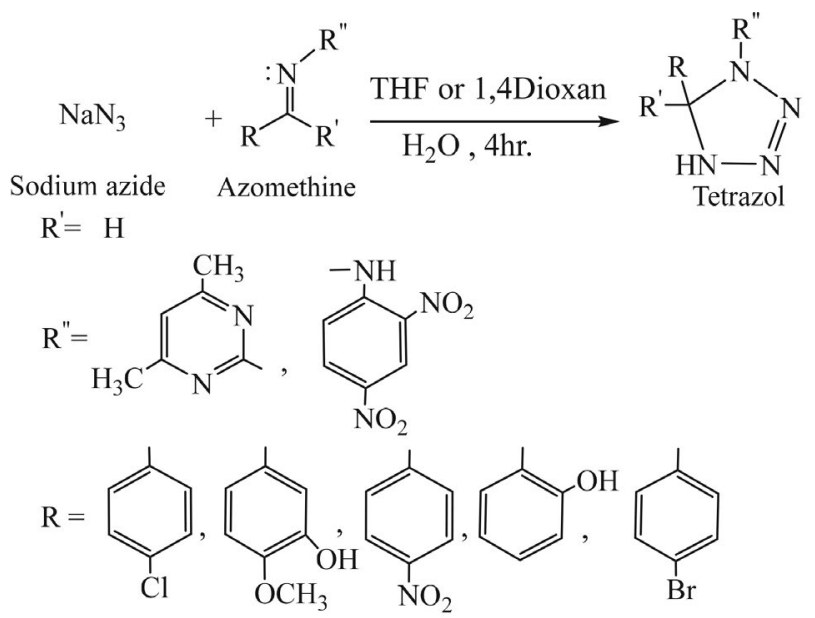

Scheme 6. The main reaction of the prepared tetrazole derivatives

From the reaction course and the suggested mechanism it may be concluded that the reaction takes place via concerted mechanism (Huisgen 1,3-dipolar cycloaddition). ${ }^{28}$

\section{3. Activity against Candida Yeasts}

Zone of inhibition of some human pathogenic yeasts was determined by the well-diffusion method and used to test the potential of the prepared tetrazole derivatives $\left(\mathbf{I}_{\mathbf{6}}{ }^{-}\right.$ $\left.\mathbf{I}_{10}\right)$ as shown in Fig. 3 and 4. Compound $\mathbf{I}_{6}$ was found to be the best derivative that has significantly $(p<0.01)$ recorded a stronger influence to inhibit the growth of Candida zeylanoides at an average of the zone of inhibition of $26.0 \mathrm{~mm}$, followed by $24.6-25.6 \mathrm{~mm}$ for the rest of the species of Candida. Next, $\mathbf{I}_{\mathbf{8}}$ derivative recorded zone of inhibition of $11.0 \mathrm{~mm}$ toward Candida guilliermondii. Furthermore, $\mathbf{I}_{7}$ and $\mathbf{I}_{9}$ showed the lowest zone of inhibition of only $8.0 \mathrm{~mm}$ against Candida zeylanoides. Additionally, $\mathbf{I}_{\mathbf{6}}$ derivative recorded zone of inhibition of $11.3 \mathrm{~mm}$ against Candida guilliermondii and Candida zeylanoides, respectively. Compound $\mathbf{I}_{\mathbf{1 0}}$ did not inhibit the growth of Candida species as shown in Fig. 3. Resistance mechanism depends on which specific paths are inhibited by the drugs

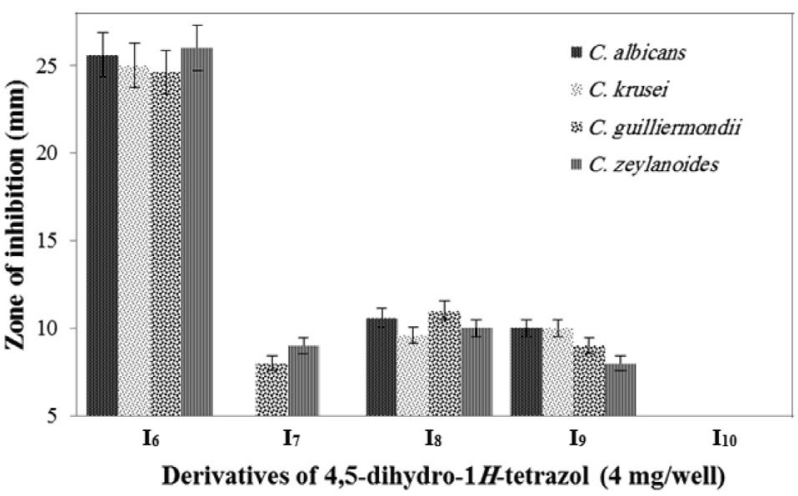

Figure 3. Zone of inhibition of Candida sp. using the prepared tetrazole derivatives 


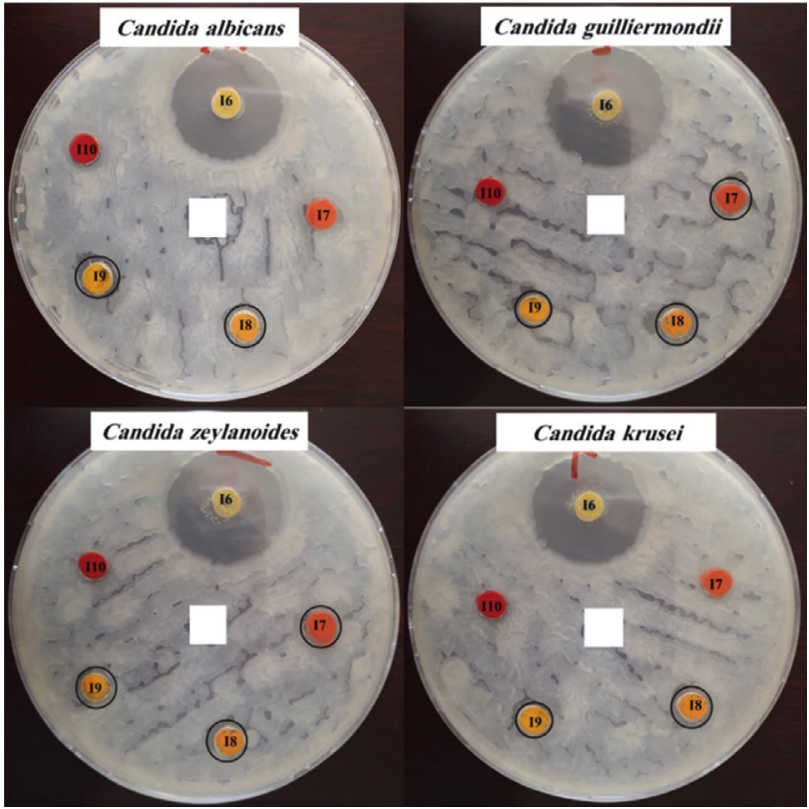

Figure 4. Activity against Candida yeasts of the prepared tetrazole derivatives $\mathbf{I}_{\mathbf{6}}-\mathbf{I}_{\mathbf{1 0}}$

and if the alternative paths are available to substitute for those paths that the compound has inhibited; in this way the microorganism can modify its pathways and be able to survive by developing resistence..$^{29,30}$ These results agree with some recent studies which described the synthesis of hybrid heterocycles proving to have in vitro antimicrobial, antibacterial and antifungal activities.

\section{Conclusions}

The results of FT-IR and ${ }^{1} \mathrm{H}$ NMR showed that the five-membered ring compounds were the least obstructed during all preparation processes and that neither light nor humidity affect the prepared compounds, this proving that the prepared compounds have an excellent stability. $\mathbf{I}_{\mathbf{6}}$ is the best derivative that has significantly $(p<$ 0.01 ) recorded a stronger influence to inhibit the growth of Candida zeylanoides at an average zone of inhibition of $26.0 \mathrm{~mm}$. This study may be helpful in designing more potential anticandidal agents for therapeutic use in the future.

\section{Acknowledgements}

Special thanks to Anbar University's President Professor Dr. Khalid Battal Najim for his continuous support to publishing the research in certified international journals, thanks to Dr. Jalal Abdul Kareem for helping to measure the ${ }^{1} \mathrm{H}$ NMR spectra. Also, grateful is for College of Education for Pure Sciences, University Of Anbar for helping to measurement the FT-IR spectra.

\section{References}

1. A. Adabiardakani, H. Mohammad, H. Kargar, World Appl. Progr. 2012, 2, 472-476.

2. M. A. Ashraf, K. Mahmood, A. Wajid, M. J. Maah, I. Yusoff, Int. Proc. Chem. Biol. Environ. Eng. 2011, 10, 1-7.

3. M. A. Ashraf, A. Wajid, K. Mahmood, M. J. Maah, I. Yusoff, Orient. J. Chem. 2011, 27, 363-372.

4. A. Golcu, M. Tumer, H. Demirelli, R. A. Wheatley, Inorg. Chim. Acta 2005, 358, 1785-1797.

DOI:10.1016/j.ica.2004.11.026

5. K. Brodowska, E. Łodyga-Chruścińska, Chemik 2014, 68, 129-134.

6. Z. Hussain, Z. Fadhil, H. Adil, M. Khalaf, B. Abdullah, E. Yousif, Res. J. Pharm. Biol. Chem. Sci. 2016, 7, 1500-1510.

7. A. A. Younus, N. R. Jber, J. Al-Nahrain Uni-Sci. 2017, 20, 1-6. DOI:10.22401/JNUS.20.2.01

8. R. Ranjith, J. Chem. Pharm. Res. 2016, 8, 505-526.

9. B. Akhlaghinia, S. Rezazadeh, J. Braz. Chem. Soc. 2012, 23, 2197-2203. DOI:10.1590/S0103-50532013005000005

10. H. A. Basheer, A. A. Ibrahim, M. S. Ahmed, Swift J. Pure Appl. Chem. 2016, 2, 1-3.

11. T. Mavromoustakos, A. Kolocouris, M. Zervou, P. Roumelioti, J. Matsoukas, R. Weisemann, J. Med. Chem. 1999, 42, 1714-1722. DOI:10.1021/jm980499w

12. N. Mekni, A. Baklouti, J. Fluorine Chem. 2008, 129, 10731075. DOI:10.1016/j.jfluchem.2008.06.019

13. D. Varadaraji, S. S. Suban, V. R. Ramasamy, K. Kubendiran, J. S. K. Raguraman, S. K. Nalilu, H. N. Pati, Org. Commun. 2010, 3, 45-56.

14. L. Myznikov, A. Hrabalek, G. Koldobskii, Chem. Heterocycl. Comp. 2007, 43 1-9. DOI:10.1007/s10593-007-0001-5

15. J. Lazarević, A. Kolarević, G. Stojanović, A. Šmelcerović, P. Ciuffreda, E. Santaniello, Acta Chim. Slov. 2018, 65, 801-810. DOI:10.17344/acsi.2018.4380

16. A. Srinivas, M. Sunitha, P. Karthik, K. V. Reddy, Acta Chim. Slov. 2017, 64, 1030-1041. DOI:10.17344/acsi.2017.3805

17. Y. J. Han, L. Wang, Q. B. Li, L. W. Xue, Acta Chim. Slov. 2017, 64, 179-185.

18. R. M. Al-Juburi, J. Al-Nahrain Uni-Sci. 2012, 15, 60-67. DOI:10.22401/JNUS.15.4.07

19. O. H. Abid, R. F. Muslim, K. M. Mohammed, J. Uni. Anbar Pure Sci. 2016, 10, 1-9.

20. R. F. Muslim, H. M. Tawfeeq, M. N. Owaid, O. H. Abid, Acta Pharm. Sci. 2018, 56, 39-57.

DOI:10.23893/1307-2080.APS.05610

21. B. P. A. M. R. B. Srinivas, Der Pharma Chemica. 2016, 8, 84-93.

22. M. N. Owaid, J. Raman, H. Lakshmanan, S. S. S. Al-Saeedi, V. Sabaratnam, I. A. Abed, Mater. Lett. 2015, 153, 186-190. DOI:10.1016/j.matlet.2015.04.023

23. R. M. A. K. M. O. Abid, J. Uni. Anbar Pure Sci. 2016, 10, 8-18.

24. O. H. Abid, H. M. Tawfeeq, R. F. Muslim, Acta Pharm. Sci. 2017, 55, 43-55.

25. J. Simek, Organic Chemistry, Pearson education, Inc., New York, 2013. 
26. O. Abid, A. Ahmed, Spectrometric identification of organic compounds, John Wiley and Sons, Inc., New York, 2005.

28. R. Das, N. Majumdar, A. Lahiri, Int. J. Radiat. Phys. Chem. 2014, 4, 467-472.
29. F. C. Tenover, Am. J. Med. 2006, 119, S3-S10.

DOI:10.1016/j.amjmed.2006.03.011

30. M. N. Owaid, R. F. Muslim, H. A. Hamad, Jordan J. Biol. Sci. 2018, 11, 401-405.

\section{Povzetek}

$Z$ reakcijo natrijevega azida s predhodno pripravljenimi azometinskimi spojinami $\mathbf{I}_{\mathbf{6}}-\mathbf{I}_{\mathbf{1 0}}$ smo v brezvodnem tetrahidrofuranu (THF) ob dodatku nekaj kapljic destilirane vode pod pogoji refluksa pripravili nekaj novih derivatov tetrazola. Azometinske spojine smo sintetizirali s termično kondenzacijo aromatskih aldehidov s primarnimi aromatskimi amini. Pripravljenim spojinam (derivatom tetrazola) smo določili antibakterijske aktivnosti ( $\mathrm{z}$ metodo difuzije $\mathrm{v}$ disku). Spojina $\mathbf{I}_{\mathbf{6}}$ se je izkazala za najbolj aktivni derivat $\mathbf{z}$ visoko $(\mathrm{p}<0.01)$ povečanim vplivom zaviranja rasti organizma Candida zeylanoides (s povprečno vrednostjo premera inhibicije $26.0 \mathrm{~mm}$ ). Derivata $\mathbf{I}_{\mathbf{7}}$ in $\mathbf{I}_{\mathbf{9}}$ pa sta izkazala najslabše inhibitorno delovanje s premerom inhibicije le $8.00 \mathrm{~mm}$ proti istemu organizmu (Candida zeylanoides). Ta študija bi lahko pomagala pri načrtovanju novih bolj učinkovitih spojin proti kvasom iz rodu Candida, ki bi bile v prihodnosti celo uporabne v terapevtske namene. 